Hew Strachan

\title{
Towards a comparative history of World War I. Some reflexions
}

In the decade or so before 1914, many European countries enjoyed a brisk trade in fictional accounts of future war. Although rooted in the realities of contemporary politics (hence their claim to realism), the images that they conjured up were frequently apocalyptic - full of foreboding, rather than of adventure. These anticipations of the war to come recognised two possible consequences of a war in Europe: that the impact would be felt in the colonies of the great powers, and that the outcome would fundamentally revise the international order. In Germany such fictions used a portentous word that anticipated not only the awful reality of such a war but also the vocabulary which in due course other peoples too would adopt: they called this war of the future Der Weltkrieg.

At one level this was no more than a statement about its scale, not a description of its geographical extent. In 1925, the Reichsarchiv's official history, although in practice solely an account of the military operations of the German armies, conducted almost exclusively within Europe, adopted Der Weltkrieg as its title. At this juncture most other nations were still talking about the Great War or (as the French still occasionally do) La Grande Guerre. Although the British had much more cause to use the title sworld war' in their official history, given that separate series of volumes covered the war in Mesopotamia, Palestine, the Cameroons and East Africa, they preferred the more restrained description, Official History of the War (which was what appeared on the spine of the books) and Official History of the Great War (the actual words on the title page). The official historians of other nations were even more modest. The Austrians, the French and the Italians all described their outputs in purely national terms, repudiating any pretension to universality, Österreich-Ungarns letzter Krieg 1914-1918, Les armées françaises dans la grande guerre, L'esercito italiano nella grande guerra, 1915-1918. Even in Germany itself the MarineArchiv, despite a remit which was more genuinely global than that of the Reichsarchiv, opted for the more exact title, Der Krieg zur See 1914-1918.

Gradually, however, Der Weltkrieg and its equivalents in other languages, the world war, la guerre mondiale, la guerra mondiale, became universal. In the 1920 s and 1930 s there were many motivations underpinning the writing of the war's history - the issue of war guilt, the justifications of its principal statesmen and generals, the process of lesson-learning by armed forces - but the most important common theme was the need to find meaning in what had happened. The bereaved wanted reassurance that their loved ones had not died in vain, and the survivors were anxious to find significance in their own experiences although they seemed dwarfed by the scale of the conflict. To call the war a sworld war was therefore a way of parking that search for meaning in a convenient spot, a point where traditional ways of accounting for war, and recounting its experiences, could be abandoned precisely because what had happened between 1914 and 1918 had no obvious precedent.

It was also a literature of warning, just as the novels about future war written before 1914 were warnings. Much that was written about the First World War in 
the 1930s, not least the war novels that multiplied in the wake of the success enjoyed in every belligerent country by Erich Maria Remarque's Im Westen nichts Neues, was designed to prevent a similar conflict in the future. The outbreak of the Second World War demonstrated that the warning had not been heeded; that the First World War was, after all, not the war to end all wars. After 1945 the notion took hold that sworld war « was now the norm, and that all future wars fought between great powers would be stotal wars

The response of historians to this widening of the concept of war was perverse: they narrowed their perspectives, their choices of subject matter manifesting an increasing introversion. Confronted by the realisation that the war of 1914-1918 had not, after all, created a new international order of any durability, they ceased to seek any positive meaning in its motivations. The notions that a revisionist Germany went to war in 1914 in order to challenge the status quo powers such as Britain, or that the United States entered it in 1917 to check Prussian militarism on the one hand or international socialism on the other, were rejected. Instead of being an object of international concern, the war became a mirror for national narratives. Between 1961 and the 1990s the focus of scholars was not global despite the fact that Der Weltkrieg was by then the title that had become all but universal in all languages. Thanks above all to Fritz Fischer, German scholars focused on the issues of German war guilt, mediated in terms of a domestic political debate rather than by the events on the battlefield which shaped that debate. Erich Ludendorff, who professed to be above all a tactician, was criticised for his politicking. In Britain the reverse happened. Here the arguments were also parochial but more narrowly military, revolving around the western front and the generalship of Douglas Haig, the British commander-in-chief in France. In 1963, two years after Fischer had published Griff nach der Weltmacht, John Terraine completed Douglas Haig: the educated soldier, a biography whose title was itself a deliberate response to those historians in Britain, led and often orchestrated by Basil Liddell Hart, who saw the British generals as >donkeys $<$. Haig was attacked (or defended) as a tactician, and his relationship with his political masters interpreted in these terms.

This divide in national treatments of the generals of the First World War has still not been bridged. Most British senior commanders of the war have now been subject to sustained analysis at the operational and tactical levels, and some of it, particularly the works of Dominick Graham, Tim Travers, Trevor Wilson, Robin Prior and Paddy Griffith, has been reflective of major scholarship. But there is no equivalent body of literature for Germany. Holger Afflerbach's biography of Falkenhayn belongs in a different tradition, an examination of strategy, at the interface between policy and military affairs, whose nearest British equivalent is David French's trilogy on Britain's conduct of the war. Moreover, in Germany Afflerbach's book stands alone, still not matched by any comparable study of either Hindenburg or Ludendorff. It is worth remarking that, although Afflerbach now has a chair, it is in a British university, not a German one, just as the biographer of Helmuth von Moltke the younger, Annika Mombauer, has also pursued a career in Britain. In France, Guy Pedroncini's magisterial treatments of Pétain, the French commander-in-chief in 1917-18, have not encouraged other scholars to examine his predecessors, Joffre or Nivelle. On the continent the operational history of the war, Kriegsgeschichte as opposed to Militärgeschichte, remains the province of serving soldiers - Michel Goya in France or Gerhard P. Groß in Germany - more than of academics. An Australian, Elizabeth Greenhalgh, the author of a study of the 
Anglo-French coalition, is writing a biography of Foch, and an American, Robert Doughty, has written the best account of the French army at war. English-language scholars, more than German or French, have responded to the British obsession with First World War generalship, but the result is that countries whose languages are more difficult for British, American or Australian historians are being shortchanged, beginning with Italy and extending across the Balkans to the Ottoman empire and Russia.

These are the countries where the greatest rewards lie for future scholarship, and where the biggest gaps lie. The end of the Cold War had the potential to exercise an important and positive influence on the historiography of the Great War: it could once again become Der Weltkrieg in reality as well as in name. The opening of the Russian archives enabled a re-examination of the Russian experience of the war freed from the teleology of the Russian revolution. The newly independent countries of eastern and central Europe sought continuities back to 1918, the moment when the collapse of the Tsarist, Ottoman and Austro-Hungarian empires conferred statehood on aspirant nationalism. Within Germany, the unification of the military archives confirmed one of Fischer's most significant contributions, his revelation that the historiographical hole left by the British bombing of the Prussian military archives in 1945 was less great than once seemed to be the case, if scholars would only look at the papers of other ministries and other German states.

So far the response has not fully matched the opportunity. The increasingly sterile debates of the 1960s have been hard to put to one side, because their main contours still constitute the accepted framework for popular assumptions. In Britain, new biographies of Douglas Haig have been published in each of 2006, 2007 and 2008. Outside Germany the war aims debate has evaporated, and the work of Fischer marginalised by the renewed realisation that the war was triggered by Vienna in response to events in the Balkans, rather than by Berlin as part of a drive for world power. But within Germany it can seem as though Fritz Fischer's work, although deeply controversial at the time, has become orthodoxy. Griff nach der Weltmacht prompted a raft of similar studies for other belligerents, whose effects were to make the debates within Germany seem less exceptional. And yet in 2004, when Der Spiegel ran a series of articles on what it called Die Ur-Katastrophe des 20. Jahrhunderts, its tone remained Fischerite, set by essays by Hans-Ulrich Wehler on the First World War as the precursor of the Second and by John Röhl on the Kaiser's responsibility for the war's outbreak.

The big development common to all countries in the historiography of the war over the last two decades has been the exponential growth in the history of mentalités, pioneered by Antoine Prost, Jay Winter, Gerd Krumeich, Annette Becker and Stéphane Audoin-Rouzeau, and physically focused on the Historial de la Grande Guerre at Péronne. Although often written as national narratives, the imitative and repercussive effects of these studies have been comparative. Beginning with the issues of memory and memorialisation, they have given voices to those individuals whose comparative insignificance meant that they were the ones struggling to find meaning in the legacy of the war. As its protagonists, like Jay Winter, have observed, much of this is the history of the banal, of kitsch, and of low - not high - culture. Many sub-sets of First World War history have benefited. Because women were among the most vocal of mourners, gender history has been one. So too has been the history of childhood. Interestingly the experience of old age, both 
during the war when the old were marginalised by the need for youth and vigour, and after it, when as parents they grieved for their sons or felt alienated from them if they survived, has not so far attracted scholars. However, it was their sense of how to remember the dead that often prevailed. Attention to the forms of commemoration has prompted a fresh awareness of the importance of religion and faith. Debates about their physical manifestations, in war memorials, churches and museums, have introduced art history to the mix. And the arts in a broader sense have been important in the fresh examination not only of war literature but also of cinema, the graphic arts and photography.

The history of mentalités belongs to the province of social history, just as on the one hand the history of operations and strategy belong to military history traditionally defined, and on the other the history of the war's origins and of war aims find their niche in diplomatic and political history. The obvious absentee in this list is economic history. In many respects it is absent, a comparatively and undeservedly neglected area of research. Immediately after the war its importance was seen to be so central that the Carnegie Endowment for International Peace embarked on a massive Economic and Social History of the War, divided into national series of volumes, many of them written by the wartime leaders in their respective fields. More than any other scholarly undertaking in the aftermath of the war, and certainly more than any of the national official histories, these books reflected the stotality c of the First World War. No consistent pattern was set for application across all nations; instead each series reflected the peculiarities of each state, some remaining rigidly focused on industrial mobilisation, others embracing agriculture, regional impacts and demography. In most countries and for most subjects these studies have never been replaced. Not all were translated into the common language of the series, English, and, Japan apart, the focus was Euro-centric, but the neutrals were represented and so too were some of the states that had not existed during the war itself but emerged from the dismemberment of the Austro-Hungarian empire.

Economic history is the area where the challenges and opportunities for future work are greatest. Take one phenomenon common to all the belligerents in 1915 shell shortage. The processes by which nations converted peacetime industries to wartime needs have still not been fully examined, or at least not in equal depth for all countries. In Britain, David Lloyd George made his wartime reputation as the overseer of this transition when he became minister of munitions in June 1915, and yet - perhaps partly for that reason - we have only hagiographic accounts of his stewardship. Moreover, the focus on 1915 has resulted in a neglect of what happened later in the war. In Germany's case, the issue of munitions output is central to the debate about the combat effectiveness of the German armies in 1918, and yet the trend is to look at the latter from the point of view of mentalités and morale if you are German and from a narrowly tactical perspective if you are British or American. Norman Stone's pioneering and still unsurpassed study of the eastern front pointed out that Russian shell production rose in 1916, but he did not go further and ask what sort of shells for what sorts of guns. By that stage of the war the key component in trench fighting was heavy artillery, and that, not more shells for field guns (although they were still crucially important), was the potent indication of modernisation and adaptability.

Economic warfare was central to the argument about how the war was won and lost, at least in the inter-war period. Thanks to Avner Offer, Anne Roehrkohl, Be- 
linda Davis and Maureen Healy, among others, we have a much better sense of the impact of hunger on civilian communities, even if the causes of that hunger remain contentious. Were shortages of food within the Central Powers more the product of maladministration than of naval blockade? The focus of scholars has been predominantly on Germany, not on its allies, and on the role of strangulation by sea, rather than of the land blockade. Much remains to be done. Not even the mechanics of the blockade have been fully explored. Espionage was central to commercial intelligence, and yet its story remains enmeshed in inter-war yarns that owed as much to fantasy and fiction as to the more mundane reality. The laws of war at sea were bent by the British to meet their own needs while conciliating the neutrals, especially the United States, and yet we have no up to date history of the application and development of international law in the war. (Isobel Hull has, however, embarked on such a study.) And have we missed the point? May be the blockade did not cause the collapse of Germany, but did it cause the collapse of its principal allies and in turn trigger that strategic crisis of confidence within $3 \mathrm{OHL}$ at the end of September?

That crisis, sparked according to Ludendorff himself not by the events on the western front but by Bulgaria's decision to seek an armistice, itself reveals why the Reichsarchiv was justified in calling the war Der Weltkrieg. Only a month before the first quartermaster general had been pursuing an agenda in the Caucasus which put him at odds with his Ottoman allies and aimed to secure raw materials in Asia the better to continue the fighting in the west. Its ultimate goal was India. In 1918, as in 1914, the war spilled outside Europe. That was the case not least because the states of Europe were imperial powers, whose overseas possessions were both assets and sources of vulnerability. We still have no firm hold on the total civilian, as opposed to military, casualties caused by the war in Europe, let alone outside Europe (and that is another massive research task in its own right). But at least we are now less likely to ignore them. Recent trends in the history of the war outside Europe owe less to the end of the Cold War than to the end of empires: subject colonial peoples have recovered the voices all but lost in the dominant narrative of imperialism. The porters employed in the campaigns of sub-Saharan Africa and the devastation of regional economies caused by the impact of war, having been part of the history of Africa, are now also becoming part of the history of the war. Nor is this just another question of mentalités and memory. Those memories have political repercussions, particularly in the Middle East. Here the history of wartime diplomacy between allies, of conflicting promises made with the aim of achieving victory rather than of creating peace, have ensured a persistent conflict, in which past and present have remained mixed in ways that are all too vital and emotive.

The corollary of global history has been comparative history. Just as Fischer's study of German war aims prompted scholars to consider the war aims of other belligerents, so in other areas innovative studies for one country can stimulate comparable work for another. Two examples where recent scholarship has had powerful and imitative effects are the importance of ideas and ideologies in 1914, and their counterpart, the phenomenon or smyth s of s war enthusiasm،. The goal of comparative history should be the integration of these national case studies into a whole. The history of war confronts a paradox: it promotes a national narrative, but war itself is a form of international interaction, which cannot be properly understood without an awareness of the events taking place on what the Duke of Wel- 
lington called the other side of the hillk. First World War scholarship is reaching the point where this sort of genuinely comparative history is now possible. For so long vibrant in Britain and France, it has become much more lively in other languages and cultures, and attracts postgraduate students of quality as well as in quantity. The major encyclopaedias of the war produced in Germany by Gerhard Hirschfeld, Gerd Krumeich and Irina Renz, and in France by Stéphane AudoinRouzeau and Jean-Jacques Becker, prompt awareness of the issues to which we do not have answers as much as those to which we do. (And the same point will no doubt be true of the Blackwell Companion on the First World War being prepared under the editorship of John Horne.) Gaps are being filled for belligerents that have been neglected hitherto: for the Balkan states, for the ethric groups of Central Asia, for China and Japan. The stories of children, of prisoners of war, and of the victims of atrocity are now being told alongside those of politicians and soldiers. As these and other areas of the canvas are painted in, a true synthesis will become increasingly realisable. 